\title{
'Guess Who? The SRB as the Accountable Actor in Legal Review Procedures'
}

Jolien Timmermans*

Jolien Timmermans, Academic assistant and doctoral researcher at the Department of European, Public and International Law of Ghent University (Ghent European

Law Institute)

\begin{abstract}
The SRM is an institutionally complex system in which it is unclear which actor is to be held legally accountable. The reason for this complexity flows from the fact that the exercise of powers is spread over a multitude of actors at different levels. Within the SRM's framework, we find both vertical and horizontal cooperative links. In relation to the vertical links, EU actors take the main decisions, while the implementation is left to national actors. Horizontal cooperative links at the EU level are also present as EU institutions and an EU agency have to act together in composite administrative procedures. This institutional set-up results in unclarity as to where responsibility lies. If legal protection is to be provided against decisions resolving significant banks, it has to be clear who should be held responsible in legal review procedures. The article's aim is to examine what issues of legal review exist and to analyse where the de facto decision-making, and thus legal responsibility, lies within the SRM's framework.
\end{abstract}

\section{Introduction}

The Single Resolution Mechanism ('SRM') is a textbook example of a composite decision-making procedure since the relevant decisionmaking powers are spread over a multitude of actors at different levels (EU, intra-EU and national).

* DOI 10.7590/187479819X15656877527232 1874-7981 2019 Review of European Administrative Law

I would like to thank the editors of this special issue, member of my supervisory committee Elise Muir, co-supervisor Merijn Chamon, Joseba Fernández Gaztea and the participants of the ACELG Workshop on 'Accountability And Control Of European Multilevel Administration: Current Challenges In EU Administrative Law', 21 January 2018, Amsterdam, for their comments on earlier versions of this work. All errors or omissions remain those of the author. 
The article will show that the SRM's architecture and its implementation is highly complex ${ }^{1}$ and that its division of powers is multi-layered. This might result in challenges for upholding the principle of effective judicial protection as guaranteed by Article 47 of the Charter of Fundamental Rights of the European Union. Indeed, trying to find out which actor is to be held accountable within the system has quite some resemblance to Hasbro's well-known guessing game 'Guess who'. This raises the question as to how accountability, understood in terms of legal review, is organised within the SRM. This article contributes to existing literature by identifying gaps in the current legal review procedures by relying on a case study of the Banco Popular ${ }^{2}$ cases currently pending at the General Court.

This article consists of three sections; the first section will outline the main features of the complex institutional framework and will show that it is unclear where responsibility lies. The second section will disclose the gaps present in the legal review procedures, and the concluding section will put forward the main argument that it is the Single Resolution Board ('SRB') that should be held responsible in legal review procedures in which the CJEU should assess the legality of a resolution decision taken by the SRB (with the involvement of the Commission and/or Council). ${ }^{3}$ The article will limit itself to the system of the SRM and the procedure in which a significant bank is resolved by the SRB ${ }^{4}$ but will not discuss the resolution of a less significant bank at national level. ${ }^{5}$ Lastly, the scope of this article is limited to identifying issues of legal review only, and not of accountability as a whole.

1 Danny Busch, 'Governance of the Single Resolution Mechanism', in Danny Busch \& Guido Ferrarini (ed.), European Banking Union (Oxford: OUP 2015) 332. European Court of Auditors, Special Report No 23/2017, Single Resolution Board: Work on a challenging Banking Union task started, but still a long way to go.

2 Banco Popular was the first significant bank to be resolved by SRB within the newly established SRM framework. For an overview of all cases you can consult, https://ebi-europa.eu/publications/eu-cases-or-jurisprudence/, accessed 1 May 2019.

3 The Banco Popular cases pending before the General Court are an example of such a case.

4 In essence the procedure of Article 18 SRMR.

5 Which is done by the NRAs under the Bank Recovery and Resolution Directive 2014/59/EU ('BRRD'). For more information on this type of resolution see: P.E. Berger \& D. Vanderstraeten, 'The Single Resolution Mechanism. Institutional and Financing Arrangements for Bank Resolution in the European Banking Union', in Robby Houben \& Werner Vandenbruwaene (ed.), The Single Resolution Mechanism (Cambridge: Intersentia 2017) 19-23. 


\section{The Institutional Framework of the Single Reso- lution Mechanism}

As mentioned supra, the overarching problem within the SRM is that the exercise of powers is spread over a multitude of actors at different levels. In order to fully grasp this issue, the article will explain why the SRM was created and will then give an overview of how the SRM system functions when a significant bank is resolved. This section will subsequently clarify the vertical and horizontal exercise of powers between the many actors involved. Finally, attention will be drawn to the governance structure's several layers of complexity. ${ }^{6}$

\subsection{Background to the SRM}

The SRM is part of the European Banking Union. The creation of the Banking Union was triggered by the financial and euro-crises. During the crises, it became clear that the then existing system of banking supervision and crisis management was not the best solution to deal with failing Eurozone banks. Among the problems that were difficult to address, were inter alia the interdependency of EU banks and the link between the sovereign and banks (i.e. the so-called 'doom loop'). The national systems of cooperation and coordination were not apt to deal with the failing large cross-border banks. As a solution to this problem, the European Council in $2012^{7}$ decided to establish a system where both the supervision and the resolution of banks would be centralised and dealt with at the Union level. ${ }^{8}$ The supervision and resolution of banks was therefore put within the broader objective of a 'European Banking Union'. ${ }^{9}$ The Banking Union consists of three pillars of which only the Single Supervisory Mechanism ${ }^{10}$ ('SSM') and the $\mathrm{SRM}^{11}$ are already functioning. There is no agreement yet between the European Parliament and the Council concerning the third pillar, i.e. the European Deposit Insurance Scheme ('EDIS'). Since 2014, the European Central Bank ('ECB') has taken on its task as a supervisor

6 Danny Busch, 'Governance of the Single Resolution Mechanism', in Danny Busch \& Guido Ferrarini (ed.), European Banking Union (Oxford: OUP 2015) 332.

7 European Council, The President, 'TOWARDS A GENUINE ECONOMIC AND MONETARY UNION. Report by President of the European Council Herman Van Rompuy', EUCO 120/12, 4 .

8 The SRM is therefore an example of Europeanisation of banking resolution.

9 Giuseppe Boccuzzi, 'The Second Pillar of the Banking Union: From the NRAs to the Single Resolution Mechanism', in Giuseppe Boccuzzi, The European Banking Union Supervision and Resolution (Basingstoke: Palgrave Macmillan 2016) 116.

10 In place since 2014 .

${ }_{11}$ In place since 2016 . 
of now 114 significant banks within the Eurozone. ${ }^{12}$ All other, so-called 'less significant' banks continue to be supervised at the national level. ${ }^{13}$ As the SRM is a necessary complement to the SSM, both should be viewed together. ${ }^{14}$ Against this background of the Banking Union, the EU also made a division regarding the resolution of banks. The 114 significant banks will be, if needed, resolved at the EU level under the SRMR. ${ }^{15}$ When the ECB (or the SRB) determines that one of the significant banks is failing or is likely to fail, the SRB will take up its role as the central institution for bank resolution in the Eurozone. The purpose of the SRM is to ensure an orderly resolution of failing banks with minimal costs for taxpayers and the economy. ${ }^{16}$

When resolution happens at EU level, the content of the resolution measures are taken by EU actors and only the implementation is done by the NRAs. This already indicates how the exercise of powers is spread vertically (EU versus national level) over a multitude of actors. This article will only focus on the procedure which entails the resolution of a significant bank under Article 18 of the SRM Regulation' ${ }^{17}$ ('SRMR') and the exercise of powers between all actors involved. This procedure has been used by the SRB and the EU institutions in order to address the problems encountered by Banco Popular. ${ }^{18}$ What adds a further layer of complexity is that at the EU level, the exercise is spread horizontally between several EU actors. It is the agency, the SRB, which has the overall responsibility for the effective and consistent functioning of the SRM. ${ }^{19}$

\subsection{The SRB's Institutional Set-up}

For the analysis on the exercise of powers, it is important to have a quick look at the SRB's internal structure. The SRB is composed of a

12 European Central Bank, 'List of Supervised Entities', July 2019, https://www.bankingsupervision.europa.eu/banking/list/who/html/index.en.html.

13 Danny Busch, 'Governance of the Single Resolution Mechanism', in Danny Busch \& Guido Ferrarini, European Banking Union (Oxford: OUP 2015) 282-283.

14 Ibid, 283-284.

15 While, the less significant banks will be resolved at national level under the Bank Recovery and Resolution Directive 2014/59/EU. When resolution happens at national level, the NRAs remain the sole responsible authority.

16 See European Commission, European Financial Stability and Integration Review (EFSIR), SWD (2017) 171 final, PART 2/2, 82.

17 Regulation (EU) 806/2014 of the European Parliament and of the Council of 15 July 2014 establishing uniform rules and a uniform procedure for the resolution of credit institutions and certain investment firms in the framework of a Single Resolution Mechanism and a Single Resolution Fund and amending Regulation (EU) 1093/2010 ('SRMR').

18 Single Resolution Board, SRB/EES/2017/08, 7 June 2017.

19 SRMR (n. 16) art 7(1). The SRB is also responsible for drawing up resolution plans and adopting all decisions relating to resolution for the entities or groups covered by the SRM, see SRMR (n. 16) art $7(2)$. 
plenary session, an executive session, a Chair ${ }^{20}$ (and Vice-Chair ${ }^{21}$ ), a secretariat and an Appeal Panel. ${ }^{22}$ The plenary session brings together the Chair, four fulltime members and one national representative from each NRA. ${ }^{23}$ Each of these members has one vote. ${ }^{24}$ The plenary session decides upon the SRB's internal matters (i.a. annual work programme, annual budget, rules of procedure, etc.) and upon the use of the Single Resolution Fund (SRF). ${ }^{25}$ The SRB's executive session is composed of the Chair and the four full-time members. ${ }^{26}$ The executive sessions prepare the decisions to be adopted by the plenary session and take all decisions in order to implement the SRMR. ${ }^{27}$ Both the Commission and the ECB are entitled to a permanent observer in both the plenary and the executive sessions. This observer is entitled to participate in the meetings, debates and shall have access to all documents. ${ }^{28}$ The observers, however, do not have voting rights. The SRMR also sets up a Board of Appeal, named the Appeal Panel. ${ }^{29}$ Its task is to offer to parties affected by certain types of SRB decisions a first layer of legal review prior to a possible appeal before the CJEU. ${ }^{30}$ The Appeal Panel is composed of five effective members and two alternates. ${ }^{31} \mathrm{Al}$ though Article 43 SRMR does not list the Appeal Panel as one of the bodies of the SRB, it is not a body external to the SRB either. In line with established jurisprudence of the Courts on the position of the Boards of Appeal of others agencies there arguably exists a functional continuity between the SRB and its Appeal Panel..$^{32}$

20 SRMR, art 56.

21 SRMR, art 56(3).

22 SRMR, art 43.

23 SRMR, art 43(1).

24 SRMR, art 43(2).

25 SRMR, art 49.

26 SRMR, art 53(1).

27 SRMR, art 54(1). For a more detailed discussion, see Robby Houben and Werner Vandenbruwaene (ed.), The Single Resolution Mechanism (Cambridge: Intersentia 2017) 15-19.

28 SRMR, art 43(3).

29 While there is no clear consensus on this point, it would go beyond the scope of this article to discuss the nature of the Appeal Panel, but see Yves Herinckx, 'Judicial Protection in the Single Reso-lution Mechanism', in Robby Houben \& Werner Vandenbruwaene (ed.), The Single Resolution Mechanism (Cambridge: Intersentia 2017), from recital 20 onwards; Dominik Skauradszun, 'Legal Protection against Decisions of the Single Resolution Board pursuant to Article 85 Single Resolution Mechanism Regulation' (2018) European Company and Financial Law Review 3. The General Court defines Boards of Appeal in general as 'quasi-juridictional bodies' in

Case T-133/08 Schräder v CPVO - Hansson EU:T:2012:430, para 137, 190.

30 SRMR, art 85. Yves Herinckx, 'Judicial Protection in the Single Resolution Mechanism', in Robby Houben \& Werner Vandenbruwaene (ed.), The Single Resolution Mechanism (Cambridge: Intersentia 2017), recital 3 .

31 SRMR, art 85(2).

32 See e.g. Case T-163/98 Procter \& Gamble v OHIM EU:T:1999:145, para 38 and Case T-102/13 Heli-Flight v EASA EU:T:2014:1064, para 27. M. Chamon, 'Les agences décentralisées et le droit procédural de l'UE' (2016) Cahiers de droit europeen 52(2), 555-556. Yves Herinckx, 'Judicial 


\subsection{Horizontal Exercise of Powers Between the EU Institutions and the SRB}

When it is established that a significant bank is 'failing or is likely to fail', ${ }^{33}$ the SRB is competent to find an appropriate solution. ${ }^{34}$ If resolution needs to happen in the public interest then the adoption of a resolution scheme will be necessary. It is the SRB who will draft the resolution scheme. ${ }^{35}$ In this case, the SRB adopts the resolution scheme in its executive session including the representatives of the relevant NRAs. ${ }^{36}$ The idea is to reach a joint agreement by consensus. ${ }^{37}$ The SRB, moreover, decides on the use of the resolution tools and possible reliance on the SRF.$^{38}$ Four tools are at the SRB's disposal, these are: the sale of business tool, ${ }^{39}$ the bridge institution tool, the asset separation tool and the bail-in tool. ${ }^{40}$ When the SRB adopts the resolution scheme, immediately after the adoption, the scheme must be transmitted by the SRB to the Commission. When it has been transmitted, the Commission has 24 hours to either (tacitly) endorse or object to the resolution scheme. Furthermore, the Council is involved if within 12 hours from the transmission of the scheme, the Commission proposes to object or to approve the resolution scheme. If the Council then objects to the placing under resolution of an institution, the relevant institution will be wound down in accordance with the applicable national law. In the event that the Commission objects or the Council

Protection in the Single Resolution Mechanism', in Robby Houben \& Werner Vandenbruwaene (ed.), The Single Resolution Mechanism (Cambridge: Intersentia 2017), recital 5.

33 Either by the ECB or by the SRB itself. It is important to note that the SRB itself can make the assessment that a bank is failing or is likely to fail. Depending on your reading, the ECB's implied consent is still necessary to assess whether or not a bank is failing or is likely to fail and as a consequence start resolution, as the ECB could still decide to make up its own assessment. The consequence being that the SRB cannot make its own assessment. SRMR, art 18(1). According to the General Court, the ECB's assessment of the failing or likely to fail condition is not binding on the SRB however, see Order in Case T-281/18 ABLV Bank AS v ECB EU:T:2019:296, para 34.

34 Please note that the analysis in this article is based on the adoption of a resolution scheme under the 'normal' decision-making procedure (i.e. no use is made of the Single Resolution Fund).

35 The Commission can only endorse or object to the resolution scheme. It cannot propose amendments.

36 SRMR, art 55 .

37 If this would not be feasible the Chair and the four full-time SRB members shall take a decision by simple majority. This means that the national members appointed by the Member States do not have voting rights when consensus cannot be reached.

38 See Article 18(6) b in conjunction with Article 22(2) SRMR.

39 In the currently challenged Banco Popular resolution before the General Court, use had been made of the 'sale of business tool'. It would go beyond the scope of this contribution to go into the specificities of all four tools but see Articles 25 to 27 of the SRMR (n. 16) and Michael Schillig, 'The EU resolution toolbox', in Matthias Haentjens \& Bob Wessels (ed.), Research Handbook on Crisis Management in the Banking Sector (Edward Elgar Publishing 2015) 81-102.

More information on the tools can be found in Articles 25 to 27 of the SRMR. 
has approved the Commission's proposal for modification, the SRB shall within eight hours modify the resolution scheme. ${ }^{41}$ At most, the procedure could take up 32 hours (24 hours to endorse/object plus eight hours if the SRB has to modify the scheme in response to the Commission's or Council's objections). This short timeframe makes it possible to adopt a resolution scheme over the weekend, in order not to disturb the financial markets. It is clear that the timing for the Commission and the Council to react and to exercise their power of endorsement is short. However, for the Commission this should pose less of a problem as in practice the Commission participates as an observer in the SRB meetings. ${ }^{42}$ If the Commission were to remain silent, a literal reading of Article 18(7) fifth paragraph, SRMR suggests that the scheme would enter into force automatically. This would have immediate effects for judicial protection as the SRB decision will directly generate legal effects for third parties without a formal endorsement decision from the Commission.

The reason why the two EU institutions (i.e. Commission and Council) have been given these powers can be found in the Court's infamous Meroni-doctrine. ${ }^{43}$ This doctrine limits the delegation of powers to agencies. ${ }^{44}$ In essence, this doctrine led the SRMR drafters to believe that the input of the EU institutions was needed only so as not to breach the CJEU's doctrine. This makes clear why in the SRM there is a distinction between the de facto actor (i.e. the SRB) and the de jure actor(s) (i.e. Commission and Council) within the SRM.

$41 \quad$ SRMR, art 18(17), 18(8).

42 Recital 26 of the SRMR gives more guidance on the observer status of the Commission: 'As an observer to the meetings of the Board, the Commission should, on an ongoing basis, check that the resolution scheme adopted by the Board complies fully with this Regulation, balances appropriately the different objectives and interests at stake, respects the public interest and that the integrity of the internal market is preserved. Considering that the resolution action requires a very speedy decision-making process, the Council and the Commission should cooperate closely and the Council should not duplicate the preparatory work already undertaken by the Commission.'

43 SRMR (n. 16), recital 26. Just before the SRMR was adopted, the Court in Short-selling refined the Meroni-doctrine by only allowing delegations to agencies insofar as the agency (i) acts on predefined criteria, (ii) cannot take autonomous decisions and (iii) is only exceptionally empowered. For a discussion of this case see, Mira Scholten \& Marloes van Rijsbergen, 'The ESMA-Short Selling Case: Erecting a New Delegation Doctrine in the EU upon the MeroniRomano Remnants' (2014) Legal Issues of Economic Integration 41(4), 389-405; Mira Scholten \& Marloes van Rijsbergen, 'Limits of agencification in the european union' (2014) German Law Journal 15(7), 1223-1256; Cristoph Ohler, 'Zur Übertragung von Rechtsetzungsbefugnissen auf die Europäische Wertpapier- und Marktaufsichtsbehörde (ESMA)' (2014) Juristenzeitung 249252; Simon Denys, 'Délégation de compétences à l'Autorité européenne des marchés financiers' (2014) Mars Comm. 3, 14-15; Laura Clément-Wilz, 'Les agences de l'Union européenne dans l'entre-deux constitutionnel' (2015) Revue trimestrielle de droit européen 337-348.

44 It would go beyond the scope of this article to go into the Meroni-doctrine and the application thereof within the SRM. 


\subsection{Vertical Division of Powers Between the SRB and NRAs}

The SRB, being the operational and decision-making body, is responsible for the effective and consistent functioning of the SRM. ${ }^{45}$ When a resolution scheme has been adopted by the EU actors, the implementation of the scheme is left to the NRAs. The resolution scheme is addressed to them and the NRAs must take all necessary measures to implement it. ${ }^{46}$ The SRB closely monitors the execution of the resolution decision by the NRAs. The NRAs, moreover, are under a duty to cooperate with the SRB. ${ }^{47}$ The NRAs exercise their resolution powers in accordance with Article 29 SRMR. ${ }^{8}$ This Article deals with the implementation of decisions taken under the SRMR. It states that the NRAs shall exercise their powers under the national law transposing the Bank Recovery and Resolution Directive 2014/59/EU ('BRRD'). They are therefore obliged to fully inform the SRB of the exercise of their powers; Any action the NRAs take must comply with the SRB's decision. ${ }^{49}$ This makes clear that a NRA has no or a very limited margin of discretion when implementing the resolution scheme and the relationship between the SRB and the NRA's is very hierarchical..$^{\circ}$ In the event, that a NRA has not applied or has not complied with a SRB decision, the SRB can take over and may directly oblige the institution under resolution to undertake certain actions. Before the SRB takes over it has to inform the Commission and the NRA of the measure it intends to take. ${ }^{11}$ When the execution of the resolution scheme has been finalised, the NRAs must submit a final report on the execution to the SRB..$^{2}$

\subsection{Conclusion on the Balance of Powers within the SRM}

Within the SRM's institutional framework, the SRB and the European Commission (being EU actors) take the main decisions in the composite procedure of Article 18 SRMR, while the responsibility for the implementation is left to the NRAs. This clearly proves the existence of vertical cooperative links. On the other hand, at the Union level EU institutions and EU agencies have to act together in the same procedure showing us the horizontal cooperative

\footnotetext{
SRMR, art 7(1).

SRMR, art 18(19).

SRMR, art 28(1).

SRMR, art $18(9)$.

SRMR, art 29(1).

Before the SRM was contemplated, De Moor-van Vugt in general terms described how a process of Europeanisation (altering the roles of national authorities and turning them into 'subcontractors') would play out. See Adrienne de Moor-van Vugt, 'Netwerken en de europeanisering van het toezicht' (2011) Tijdschrift voor Europees en economisch recht 59(3), 94-102.

SRMR, art 29(2).

Article 28(1) in fine, SRMR.
} 
links. The SRB takes de facto decisions which are formally endorsed by the Commission (or the Council). This means that either the Commission or the Council will be the de jure author of the decision. This is indeed a delicate balance with a complex decision-making mechanism involving mainly the SRB, the Commission and the Council. ${ }^{53}$ As stated by Busch, the SRM's governance structure features not one but several layers of complexity. ${ }^{54}$ This complexity can be found in the division of tasks both vertically and horizontally. The SRM's decision-making process requires the intervention of many parties within a very limited timeframe. ${ }^{55}$ As a consequence of this institutional set-up, the attribution of wrongful decision-making under the SRM is unclear for the fora reviewing the resolution decision(s) brought before them.

\section{Legal Review}

This section will provide a succinct overview of the several avenues for legal review in which the SRMR foresees. Additionally, this section will lay bare gaps in legal review which exist within the SRM's system. Throughout the analysis referral will be made to the current Banco Popular cases currently pending at the General Court, so as to make the link between the theory in the SRMR and the practice.

\subsection{Types of Legal Review within the Single Resolution Mechanism}

The article identifies two types of legal review within the SRM, being administrative and judicial review. The reality of legal review within the SRM is complex. ${ }^{56}$ The recitals of the SRMR provide us with an outline of how decisions can be legally reviewed:

'The SRM brings together the Board, the Council, the Commission and the resolution authorities of the participating Member States. The Court of Justice

53 Giuseppe Boccuzzi, 'The Second Pillar of the Banking Union: From the NRAs to the Single Resolution Mechanism', in Giuseppe Boccuzzi (ed.), The European Banking Union Supervision and Resolution (Basingstoke: Palgrave Macmillan 2016) 120.

54 Danny Busch, 'Governance of the Single Resolution Mechanism', in Danny Busch \& Guido Ferrarini (ed.), European Banking Union (Oxford: OUP 2015) 332.

55 Rudi Bonte, 'Concluding Remarks on Resolution and Resolvability Challenges', in Robby Houben \& Werner Vandenbruwaene (ed.), The Single Resolution Mechanism (Cambridge: Intersentia 2017) 137 .

56 Dominik Skauradszun, 'Legal Protection against Decisions of the Single Resolution Board pursuant to Article 85 Single Resolution Mechanism Regulation' (2018) European Company and Financial Law Review 123, 1. 
has jurisdiction to review the legality of decisions adopted by the Board, the Council and the Commission, in accordance with Article 263 TFEU, as well as for determining their non-contractual liability. Furthermore, the Court of Justice has, in accordance with Article 267 TFEU, competence to give preliminary rulings upon request of national judicial authorities on the validity and interpretation of acts of the institutions, bodies or agencies of the Union. National judicial authorities should be competent, in accordance with their national law, to review the legality of decisions adopted by the resolution authorities of the participating Member States in the exercise of the powers conferred on them by this Regulation, as well as to determine their non-contractual liability. ${ }^{57}$

This outline seems at first sight to be rather straightforward, but as we will see throughout the article, the reality is more complex.

\subsubsection{Administrative Review}

The Administrative board of review within the SRM is called the 'Appeal Panel'. It is the first form of legal review provided for private parties who are affected by the SRB's decision. This review is easier, faster and cheaper compared to review before the EU courts. The members of the Appeal Panel are legal scholars, lawyers and economists which has as its consequence that the Appeal Panel is very well equipped to assess the complex, technical and economic assessments the SRB has made within the SRM framework. The SRMR itself does not mention on what grounds the Appeal Panel can review decisions. Herinckx and Morais submit that the Appeal Panel will assess the legality of the decision but it will not assess whether it was appropriate or opportune to take the decision. ${ }^{58}$ According to Herinckx, the applicable standard of review by the Appeal Panel is that of 'error of assessment'. It however, does not need to be manifest as the Appeal Panel is well equipped to investigate thoroughly whether or not the economic assessment made by the SRB was erroneous. ${ }^{59}$ Some legal scholars believe it is unclear ${ }^{60}$ whether only the legality of the measure can be challenged or whether the Appeal Panel can also review

57 SRMR, recital 120.

58 Luis Silva Morais, at Banca d'Italia and EBI Conference, 'Judicial review in the Banking Union and in the EU Financial Architecture', Rome, 21 November 2017. Yves Herinckx, 'Judicial Protection in the Single Resolution Mechanism', in Robby Houben \& Werner Vandenbruwaene (ed.), The Single Resolution Mechanism (Cambridge: Intersentia 2017), recital 24.

59 Yves Herinckx, 'Judicial Protection in the Single Resolution Mechanism', in Robby Houben \& Werner Vandenbruwaene (ed.), The Single Resolution Mechanism (Cambridge: Intersentia 2017), recital 26

6o Luigi Lonardo, 'The Banking Union: Agencies and the Lesson from the US' (Birmingham Law School Institute for European Law Working Paper Series) [2016/07], 8. Lonardo explains this is unclear as the SRMR does not mention on what grounds the AP can review the decisions. 
procedural and technical aspects as well as look into the merits of the contested decision. ${ }^{61}$ Claimants are obliged to first bring an appeal before the Appeal Panel, if the decision falls within the scope of Article 85(3) SRMR. If the claim does not fall within the Article's scope, the claimant needs to initiate a procedure before the EU courts. The Appeal Panel thus has no general appellate jurisdiction over all SRB decisions. ${ }^{62}$ In combination with the strict admissibility criteria ${ }^{63}$ which mirror Article 263 TFEU, many cases have been declared inadmissible before the Appeal Panel. ${ }^{64}$ Indeed Herinckx, who has acted as Vice-Chair of the Appeal Panel, notes that the case law of the CJEU is taken into account in order to decide upon the locus standi of the appellant. ${ }^{65}$ If and when a case is admissible and the Appeal Panel decides on a case, its decision is binding for the SRB. The Appeal Panel thus acts independently from the SRB. ${ }^{66}$ The Appeal Panel can only confirm the SRB decision or remit the case to the SRB. It itself cannot amend the SRB decision or take a decision replacing the SRB decision. ${ }^{67}$ The time limit to initiate proceedings is six weeks but the Appeal Panel itself is also subject to strict limits as it has to decide on appeals within one month. ${ }^{68}$ The Appeal Panel's decision is furthermore subject to an action for annulment before the General Court. If such an appeal would indeed be lodged before the General Court, it will only exercise limited review. It will assess whether there was respect for procedural rules, whether the facts were correctly assessed and whether the decision was vitiated by a manifest error of assessment. The General Court will therefore not assess whether or not the technical or economic assessment was correctly decided.

\subsubsection{Judicial Review at EU Level}

Cases can come before the EU courts in four ways: as an appeal against a decision of the Appeal Panel, action for annulment against an SRB decision, action for damages or as a preliminary reference from a national

61 Paola Chirulli and Luca De Lucia, 'Specialised Adjudication in EU Administrative Law: the Boards of Appeal of EU Agencies' (2015) European Law Review 40(6), 832, 846. Chirulli and De Lucia believe the applicants are able to challenge more than only the legality of the measure.

62 The list is to be found in Article 85(3) SRMR.

$6_{3}$ Direct and individual concern and the six week time limit.

64 SRMR, art 85(3). Dominik Skauradszun, 'Legal Protection against Decisions of the Single Resolution Board pursuant to Article 85 Single Resolution Mechanism Regulation' (2018) European Company and Financial Law Review 123, 3 (80,33\% in 2017).

65 Yves Herinckx, 'Judicial Protection in the Single Resolution Mechanism', in Robby Houben \& Werner Vandenbruwaene (ed.), The Single Resolution Mechanism (Cambridge: Intersentia 2017), recitals $14-23$.

66 SRMR, art 85(2), 85(5).

67 SRMR, art 85(8).

68 SRMR, art 85(4). 
court. A succinct overview of each of these procedures will be given under the following headings.

\section{Appeals Against Decisions of the Appeal Panel}

Article 86(1) SRMR provides that an Appeal Panel decision can be further appealed before the Court of Justice (i.e. the General Court). A subsequent appeal against the General Court's decision can be made to the Court of Justice under general EU law (i.e. Article 256(1) TFEU). ${ }^{69}$ It is important to note that when the Appeal Panel has jurisdiction, the challenge must be brought before the Appeal Panel before an appeal can come before the General Court. ${ }^{70}$ A further question arises regarding which party can lodge an appeal before the General Court; Article 86(1) SRMR provides no guidance on this question. It seems logical that the party which lodged a proceeding before the Appeal Panel and which lost its case there, will be able to lodge an appeal before the General Court. The SRB will have been the defendant before the Appeal Panel and thus, it too could lodge an appeal before the General Court. However, this is not entirely clear as the SRB is bound by the Appeal Panel's decision (see Article 85(8) SRMR). The defendant before the General Court will be the SRB and not the Appeal Panel as it is the SRB which has to implement the Appeal Panel's decision, meaning we would end up having a case SRB versus SRB before the General Court. Herinckx argues ${ }^{71}$ that the SRB is allowed to challenge the Appeal Panel's decision as the standing criteria (mirroring Article $26_{3}$ TFEU) are the following: the contested act must be 'addressed to that person or be of direct and individual concern to them'.$^{72}$ The decision of the Appeal Panel is addressed to the SRB, which means the SRB would have locus standi before the General Court. Herinckx further argues that from a policy perspective, the SRB 'must be in a position to submit possible error of judgment made by the Appeal Panel to the review of a higher body'. ${ }^{73}$ This is another example of unclarity and thus complexity within the SRM legislation.

69 Article 256(1) Consolidated Version of the Treaty on the Functioning of the European Union (TFEU) [2016] OJ C202/1 (hereafter: TFEU). However following the latest amendment of the Court's statute this has changed for decisions of the Boards of Appeal of EUIPO, CPVO, ECHA and EASA. Following appeals before the General Court only an exceptional review by the Court is possible, not an appeal. See Regulation (EU, Euratom) 2019/629 of the European Parliament and of the Council of 17 April 2019 amending Protocol No 3 on the Statute of the Court of Justice of the European Union [2019] OJ L111/1.

70 SRMR, art 86(1).

71 Yves Herinckx, 'Judicial Protection in the Single Resolution Mechanism', in Robby Houben \& Werner Vandenbruwaene (ed.), The Single Resolution Mechanism (Cambridge: Intersentia 2017), recital 29. Herinckx acted as Vice-Chair of the Appeal Panel.

72 TFEU, art 263(4).

73 Yves Herinckx, 'Judicial Protection in the Single Resolution Mechanism', in Robby Houben \& Werner Vandenbruwaene (ed.), The Single Resolution Mechanism (Cambridge: Intersentia 2017), recital 29. 


\section{Actions for Annulment by Natural and Legal Persons Against SRB Decisions}

An action for annulment can only be initiated before the General Court if the appellant would not have the possibility of introducing an appeal before the Appeal Panel. The Banco Popular cases are an excellent example of this route. ${ }^{74}$ It is highly important for the appellant to verify whether or not his or her complaint could fall within the scope of review of the Appeal Panel. If the appellant makes a mistake, the time limit of two months (in which the action for annulment has to be lodged) may by then already have elapsed. In order to avoid such a scenario, the appellant could introduce parallel proceedings, before the Appeal Panel and before the General Court. If the appeal is inadmissible before the Appeal Panel, this will not affect the action for annulment before the General Court. The most difficult hurdle to overcome for the appellant is proving his or her locus standi. The locus standi is accepted in three scenario's: when the SRB decision is addressed to him; because he meets the direct and individual test as interpreted by the Court in the Plaumann case, ${ }^{75}$ or because the contested act is a regulatory measure that directly concerns him and does not require implementing measures.

When applying the Court's case law on Article 263(4) TFEU to the pending Banco Popular cases, ${ }^{76}$ it first has to be established whether the contested act is a measure of individual or general application. In the case of Banco Popular, the SRB's resolution decision was addressed to the Spanish NRA (FROB). ${ }^{77}$ If the SRB's decision is considered by the General Court to be a measure of individual application, the applicants will have to argue that they are part of a closed group..$^{78}$ The shareholders and creditors of Banco Popular consist of a group of

74 Because the SRB decision was based on Article 18 SRMR which is not one of the grounds listed in Article 85 SRMR and accordingly does not fall within the jurisdiction of the Appeal Panel.

75 Case 25/62 Plaumann \& Co. $v$ Commission of the European Economic Community EU:C:1963:17, para 107 .

${ }_{76}$ In which the shareholders and creditors of Banco Popular challenge the SRB's resolution decision.

77 However, this does not necessarily mean that it is a measure of individual application. See Joined Cases C-622/16 P to C-624/16 P Scuola Elementare Maria Montessoriv European Commission EU:C:2018:873, para 20-39. If it is not a measure of individual application, the applicant will have to show it is challenging a regulatory act. See Case C-583/11 P Inuit Tapiriit Kanatami and Others vParliament and Council EU:C:2013:625, para 58-61.

78 Koen Lenaerts, Ignance Maselis \& Kathleen Gutman, EU Procedural Law (Oxford: OUP 2014) 324, recital 7.98. Case C-362/o6 P Markku Sahlstedt and Others v Commission EU:C:2009:243, para 30 . However, Herinckx argues that shareholders and creditors of the institution concerned should in most circumstances be regarded as 'mere members of a class and should therefore not have standing to file an action for annulment before the CJEU'. See Herinckx (n. 28), recital 36. 
persons who were identifiable at the time of adoption of the resolution scheme. ${ }^{79}$ It is of course a different question whether they have an interest in bringing proceedings separate from Banco Popular itself. In a recent order the General Court accepted that persons that were shareholders of a bank at the time that bank's authorization was revoked were individually concerned by the decision revoking the authorization since it effectively limited their rights as shareholders to instruct the bank's management bodies to take legal action. ${ }^{8 \circ}$ Assuming that Banco Popular is no longer able to autonomously act in its own interest, it is submitted that the General Court's reasoning is equally applicable to the shareholders of Banco Popular at the time of the sale of Banco Popular to Banco Santander.

Regardless whether the act is of general (and therefore a regulatory act) or individual application, the claimants will secondly, have to satisfy the direct concern test. ${ }^{81}$ Most decisions from the SRB are addressed to the NRAs. ${ }^{82}$ It is then the NRA's duty to implement the SRB decision at national level. The direct concern test will not be satisfied in the situation where the SRB decision leaves a margin of discretion to the NRA. ${ }^{83}$ The Banco Popular cases show how the competent NRA, the FROB, did not have a margin of discretion when it was implementing the SRB decision. In addition to be of direct concern, the decision must also be capable of directly producing an effect on the legal situation of the appellants. ${ }^{84}$ For the shareholders, it is argued that the imposed sale of Banco Popular affected both the substance and the extent of their rights as it took away

79 E.g. Case 11/82 SA Piraiki-Pitraiki and Others $v$ Commission of the European Communities EU:C:1985:18, para 31. Case C-152/88 Sofrimport SARL v Commission of the European Communities EU:C:1990:259, para 11.

80 Order T-247/16 Trasta Komercbanka and Others $v$ ECB EU:T:2017:623, para 62. We consider that the position of the shareholders of Banco Popular is similar to the position of shareholders of a bank which has been liquidated as a result of the withdrawal by the ECB of the bank's authorization for taking up the business of credit institutions. An appeal against this order is pending before the Court at the moment of writing. Advocate-General Kokott considers that an action could still have been brought by the bank itself, suggesting that the shareholders do not have an interest in bringing proceedings. See Opinion of AG Kokott in Joined Cases C-663/17 P, C-665/17 P and C-669/17 P Trasta Komercbanka and Others v ECB EU:C:2019:323, para 128.

81 For the Court's traditional test, see i.a. C-463/10 P and C-475/10 P Deutsche Post AG and Federal Republic of Germany v European Commission EU:C:2011:656, para 66. See also Case 97/85 Deutsche Lebensmittelwerke v European Commission EU:C:1987:243, para 11. C-131/92 Thierry Arnaud and others $v$ Council of the European Communities EU:C:1993:200, para 8.

82 See Article 29(1) SRMR.

83 Tomas M.C. Arons, 'Judicial Protection of Supervised Credit Institutions in the European Banking Union', in Danny Busch \& Guido Ferrarini, The European Banking Union (Oxford: OUP 2015) 462, recital 13.62. And B.J. Drijber, 'De Europese Bankenunie op weg naar voltooiing: het gemeenschappelijk afwikkelingsmechanisme’ (2015) SEW 220, 230-231.

84 Koen Lenaerts, Ignace Maselis \& Kathleen Gutman, EU Procedural Law (Oxford: OUP 2014) 319, recital 7.92. 
their right to receive dividends and their possibility of exercising their voting rights or their rights to take part in the management of the company. ${ }^{85}$

The above analysis deals with shareholders of the financial institution. However, it could well be that the financial institution itself also wants to challenge the SRB's decision. Nonetheless it is not obvious whether the bank itself can, in reality, still pursue legal remedies as Banco Santander gained sole control over Banco Popular as of the date on which the resolution decision was taken. In the hypothesis that Banco Popular can no longer initiate an action for annulment against the SRB decision, it is even more pivotal that the General Court accepts the shareholders' and creditors' locus standi in light of the principle of effective judicial protection. Whether this is possible depends on whether or not the NRA had a margin of discretion when implementing a decision. If it had, the decision is shielded from review as it does not satisfy the direct concern test. This means that only the national implementation measures can be challenged before national courts. This outcome is evidently not satisfactory as the real author of the decision is not NRA, but is the SRB. When the court has to decide which actor is responsible it should asses where the de facto final decisionmaking power lies. It is submitted by the author that in this case this would indeed be with the SRB.

Another remaining unclarity consists of the standard of review the General Court will apply when assessing the legality of the resolution decision. ${ }^{86}$ If the author of a contested act exercises a discretionary power, the General Court might only declare the resolution decision invalid when it is vitiated by a 'manifest error of assessment', or when it is arbitrary or clearly unreasonable. ${ }^{87}$ Whether this type of judicial restraint is always desirable, for example when fundamental rights ${ }^{88}$ are involved, can of course be questioned.

The SRB has a 'technical discretion', ${ }^{89}$ which means that it acts as an administrative body and that its discretion and limited judicial review is justified by

85 Similarly, see Order T-247/16 Fursin and Others v ECB EU:T:2017:623, para 66-69.

86 Until the first judgments by the General Court on Banco Popular are available.

87 Janneke Gerards, 'Pluralism, Deference and the Margin of Appreciation Doctrine' (2011) European Law Journal 8o, 80-120. Lenaerts, Maselis \& Gutman (n. 83) 385, recital 7.18o. In the ECJ's Tetra Laval judgment of 2005 for example, the Court stated: 'Whilst the Court recognizes that the Commission has a margin of discretion with regard to economic matters, that does not mean that the Community Courts must refrain from reviewing the Commission's interpretation of information of an economic nature.' Case C-12/03 P-DEP Tetra Laval BVv European Commission EU:C:2005:87, para 39.

88 Such as the right to property for example.

89 See by analogy Case C-40/03 P Rica Foods (Free Zone) NVv Commissionof the European Communities EU:C:2005:93, Opinion of AG Léger, paras 45-46. Miro Prek \& Silvere Lefèvre, “'Administrative Discretion", "Power Of Appraisal" And “Margin Of Appraisal” In Judicial Review Proceedings Before The General Court' (2019) Common Market Law Review 56(2), 339. 
the complexity of the economic, legal and political assessments the SRB has to make. It might be suggested that the judges call in external expertise when technical questions come before it, $9^{\circ}$ but in practice the Court makes very limited use of this possibility. Specifically, for decisions taken under the SRMR, however, it is put forward that calling in such external expertise is not necessary at all since there is a specialised Appeal Panel. However, the biggest drawback to this suggestion is that the Appeal Panel's jurisdiction ratione materiae is very limited. As demonstrated by the flood of annulment actions against Banco Popular's resolution, many SRB decisions cannot be reviewed by the Appeal Panel and have to be challenged directly before the General Court. ${ }^{91}$

\section{Action for Damages - Liability}

In Article 87 SRMR (governing the liability of the SRB) we read that jurisdiction regarding non-contractual liability claims are granted to the CJEU. ${ }^{2}$ The liability of the SRB concerning non-contractual liability in essence mirrors the general principle of non-contractual liability codified in Article 340(2) TFEU regarding non-contractual liability of the Union. Article $87 \mathrm{SRMR}$ also foresees in a compensation for damages (i.e. an indemnity provision ${ }^{93}$ ) which is not related to unlawful conduct. If the wrongful conduct can be attributed to both the SRB and the NRA, there may be joint liability of both. In this case the claim should be split between the CJEU and the national court. In that case, the CJEU might require that all national remedies are exhausted first. ${ }^{94}$ The action for damages is different from all other direct actions as it is a compensatory action aimed at making good the harmful consequences that an EU measure/conduct or omission by an EU institution has on an applicant. All other direct actions are aimed at obtaining a declaration from the Court that a Member State or an EU institution has breached European Union law. ${ }^{95}$ Since the Bergaderm judgment ${ }^{96}$ the CJEU has unified the three fundamental criteria for substantive damages liability. These are in essence the following: (1) a rule of law granting

Case C-269/90 Technische Universität München v Hauptzollamt München-Mitte EU:C:1991:317, Opinion of AG Jacobs, para 13 .

$91 \quad$ SRMR, art 85(3).

$9^{2} \quad$ SRMR, art $87(1),(3)$ and (5).

93 Yves Herinckx, 'Judicial Protection in the Single Resolution Mechanism', in Robby Houben \& Werner Vandenbruwaene (ed.), The Single Resolution Mechanism (Cambridge: Intersentia 2017), recital 43 .

94 Ibid, recital 44.

95 Albertina Albors-Llorens, 'Judicial protection before the Court of Justice of the European Court', in Catherine Barnard \& Steve Peers (ed.), European Union Law (Oxford: OUP 2017) 268.

96 Case C-352/98 P Laboratories Pharmaceutiques Bergaderm and Jean-Jacques Goupilv Commission of the European Communities EU:C:2000:361, paras 41-42. 
rights to individuals, ${ }^{97}(2)$ this rule has been breached in a sufficiently serious manner, and (3) there is a causal link between the damage and the action/inaction by the EU or the Member State. An extensive discussion of this criteria would go beyond the scope of this article, which is why only the potential legal issues the claimants would encounter in an action for damages will be touched upon. In order to be successful in showing a sufficiently serious breach, it is decisive whether the EU body (e.g. the SRB) had a large or narrow discretion when adopting the act in question. If it had a large margin of discretion, a sufficiently serious breach is required. The SRB will have had a large discretion in a resolution case as its decision is based upon complex technical and economic assessments. The CJEU will take into account that the EU body often has to make difficult discretionary choices. However, as stated above, there are judges who will not be intimidated by complex, technical and economic questions and will try to assess in depth whether the assessment made is affected by a (manifest) error of assessment. ${ }^{9}$

\section{Preliminary References from National Courts}

Under Article 267 TFEU, the CJEU is competent to hear preliminary references from national courts on the interpretation and validity of acts with European law. A reference from a national court can be send in a procedure where a decision of the NRA is challenged or whether the national court has to assess the non-contractual liability of the NRA. As discussed before, the NRAs are competent to implement the SRB decisions and the margin of discretion can vary from none to quite some discretion. When the NRA has a certain margin of discretion, this can mean that the SRB decision cannot be challenged before the General Court because the direct concern test is not satisfied. The only way in which the original SRB decision can then be challenged is via the indirect route of Article 267 TFEU. If the national court is of the opinion that the SRB decision is valid, it will not refer a question to the CJEU. National courts, according to the Fotofrost doctrine of the CJEU, ${ }^{99}$ are of course not entitled to declare an EU act invalid. Lastly, there can exist a duty to refer for a national court when it is the court adjudicating in last instance and no further judicial remedy is available. ${ }^{100}$

97 See also Tomas M.C. Arons, 'Judicial Protection of Supervised Credit Institutions in the European Banking Union’, in Danny Busch \& Guido Ferrarini (ed.), The European Banking Union (Oxford: OUP 2015) 470, recital 13.6.

98 See for example AG Jacobs' view in his Opinion in Technische Universität München: 'The Court cannot shy away from technical questions and must in an appropriate case be prepared to resolve such questions by commissioning an expert's report under its rules of procedure.' Case C-269/90 Technische Universität München v Hauptzollamt München-Mitte EU:C:1991:317, Opinion of AG Jacobs, para 13.

99 Case C-314/85 Foto-Frost v Hauptzollamt Lübeck-Ost EU:C:1987:452, paras 14-17.

100 TFEU, art 267(3). 


\subsubsection{Judicial Review at National Level}

National courts are competent to adjudicate on several decisions made within the SRM framework. They are mainly competent to review the legality of decisions adopted by the NRAs in the exercise of the powers conferred on them by the SRMR and to determine the NRAs non-contractual liability. ${ }^{101}$ As we have seen, firstly, they are competent to entertain a dialogue with the CJEU by sending preliminary references either on the interpretation or on the validity of EU acts. Secondly, they are allowed to approve ex-ante crisis management measures taken by NRAs. ${ }^{102}$ Thirdly, they can entertain a challenge against a valuation of assets and liabilities. A valuation of assets and liabilities ${ }^{103}$ plays an important role in the resolution of a bank. Usually, there are two valuations: one before the resolution and one after the resolution. These are to be carried out by an independent third person. ${ }^{104}$ The pre-resolution valuation is an integral part of the SRB's resolution decision. The SRMR foresees that the pre-resolution valuation can only be subject to appeal together with the SRB's resolution decision. ${ }^{105}$ Some of the shareholders of Banco Popular have indeed challenged the valuation decision together with the SRB decision before the General Court. ${ }^{106}$ As stated by Herinckx, there is no mention of a right of appeal against the 'post-resolution valuation' but some judicial review should be available in light of the principle of effective judicial protection enshrined in Article 47 CFR. The legal issue lies in the fact that the author of the valuation is an independent third person, not the SRB nor the NRA. If a claim would be brought before a national court, it might not be able to refer a question to the CJEU as it is not an act of an EU organ. ${ }^{107}$ This is not a desirable situation in light of effective judicial protection.

101 SRMR (n. 16), recital 120.

102 The judicial approval of ex-ante crisis management measures will not be discussed in the article as it deals with the system under the Bank Recovery and Reso-lution Directive 2014/59/EU and is not foreseen in the SRMR. But see: Yves Herinckx, 'Judicial Protection in the Single Resolution Mechanism', in Robby Houben \& Werner Vandenbruwaene (ed.), The Single Resolution Mechanism (Cambridge: Intersentia 2017), recital 49.

103 Or multiple valuations.

104 SRMR (n. 16) art 20(1) and (16).

105 SRMR (n. 16) art 20(15).

106 By using the action for an annulment procedure under Article 263 TFEU.

107 Yves Herinckx, 'Judicial Protection in the Single Resolution Mechanism', in Robby Houben \& Werner Vandenbruwaene (ed.), The Single Resolution Mechanism (Cambridge: Intersentia 2017) 45, recital 53 . 


\section{Conclusion}

As the exercise of powers is spread over a multitude of actors at different levels within the SRM's framework, the existent regime of legal review is equally complex. It is clear that in theory no measure within the SRM is immune from review. Recital 120 of the SRMR sets out a clear division of tasks between the EU courts and the national courts. It indeed refers to all traditional avenues of review, i.e. Articles 263, 267 and 340 TFEU. From a purely theoretical point of view it can be argued that a 'full regime of legal protection' is present. However, it has also become clear that there are many limitations to legal review and that theory does not necessarily align with the practice. The complex division of powers within the SRM's framework has been established in the first section and has shown that it is unclear which actor should be held legally accountable for the resolution decision. Thus, the question arises, whether this is the de facto author, i.e. the SRB or the de jure author, the Commission and/or the Council. It is the author's view that the SRB is to be held accountable in legal review procedures in which the CJEU should assess the legality of a resolution decision taken by the SRB (with the involvement of the Commission and/or Council), because essentially the real decision-making power lies with the SRB. Another possible solution to address this issue can be to hold the actors jointly accountable. In this article it has moreover been established that the rules on standing for applicants are strict (i.e. individual and direct concern test), that the EU Courts might show judicial restraint when assessing the validity of a resolution decision, that it is not always clear which party is able to initiate a proceeding and that applicants have to abide by a strict time-limit of two months, which can lead to the introduction of parallel proceedings and thus also diverging outcomes. In the Banco Popular cases, for example, it is not set in stone that the shareholders even have a legal interest in bringing a case. If the General Court would annul the SRB's decision to sell Banco Popular to Banco Santander, it is entirely impossible to become shareholders of Banco Popular again as it does not exist anymore. With regards the administrative review by the Appeal Panel, it is positive that its members are very well equipped to assess complex, technical and economic assessments. However, its jurisdiction to review SRB decisions is fairly limited. A greater role for the Appeal Panel would be a solution to the issue that the SRB decisions are technically too complex for judges to properly evaluate. In the author's opinion it is however still too early to provide an answer to the accusation whether this complex system of EU governance, lacks legal accountability. It is true that several issues of legal review can be identified, but it might be the case that the Union courts will make sure that these gaps in legal protection are addressed in its case law. Before the Banco Popular cases are decided, we can not provide a definite answer as to whether such an accusation is indeed justified or not. 